\title{
NUTRIENT PROFILE OF FIVE FRESHWATER FISH SPECIES
}

\author{
B.N. Paul ${ }^{\text {* }}$, S. Bhowmick ${ }^{1}$, S. Chanda ${ }^{1}$, N. Sridhar ${ }^{2}$ and S.S. Giri ${ }^{3}$ \\ ${ }^{1}$ Regional Research Centre of ICAR-CIFA,P.O. Rahara, Kolkata-700 118, West Bengal, India \\ ${ }^{2}$ Regional Research Centre of ICAR-CIFA, Hessaraghatta Lake, P.O.: Hessaraghatta \\ Bangalore-560 089, Karnataka, India \\ ${ }^{3}$ ICAR-Central Institute of Freshwater Aquaculture, Kausalyaganga \\ Bhubaneswar-751002, Odisha, India
}

\begin{abstract}
The nutrient profile of five freshwater fish species viz., Mystus vittatus, Ompok bimaculatus, Channa striata, Wallago attu and Pangasianodon hypophthalmus were studied. The proximate composition data shows that the moisture and fat content differed significantly $(P<0.01)$ among the fish species. The fat content was significantly higher in $P$. hypophthalmus and $M$. vittatus. The moisture was significantly higher in C. striata. The potassium content was significantly $(p<0.01)$ higher in C.striata. M.vittatus shows higher content of calcium. The other trace minerals like iron, copper and zinc contents of fish did not differ significantly among the species. The vitamin A content is maximum in O.bimaculatus whereas vitamin D content is higher in Mystus vittatus. The palmitic acid was significantly $(p<0.01)$ higher in $M$. vittatus. The oleic acid was significantly $(p<0.01)$ higher in $C$. striata and $W$. attu. The linoleic acid content was significantly $(p<0.05)$ higher in $P$. hypophthalmus. One of the important PUFA i.e. DHA was significantly higher in $O$. bimaculatus and C.striata. The PUFA content was significantly $(p<0.05)$ higher in O.bimaculatus and P.hypophthalmus. Among the amino acids, arginine, histidine, threonine and isoleucine were higher in P.hypophthalmus. C.striata and W. attu contain high amount of Tryptophan. Glutamic acid was high in O.bimaculatus and Aspartic acid was high in C. striata. The energy content was maximum in $P$. hypophthalmus. The nutrient profile of these fish species revealed that they were rich in all the essential nutrients required by human being. The information on nutrient profile of fish will give a guideline to dieticians, nutritionists, medical practitioners, researchers to advice consumers to take fish in their daily diet as a health food.
\end{abstract}

Keywords: Amino acid, Fatty acid, Freshwater fish, Mineral and vitamin, Proximate composition.

\footnotetext{
*Corresponding author email: bnpaulcifa@gmail.com
} 
B.N. Paul et al.

\section{INTRODUCTION}

Fish is a healthy food and is a major player in human nutrition, ensuring about $20 \%$ of protein intake to a third of the world's population which is more evident in developing countries (Bene et al., 2007). India is a global biodiversity hotspot and harbours more than $10 \%$ of the global fish diversity and thereby has the potential to meet the daily requirement of the essential nutrients for human health and can also provide food and nutritional security (Mohanty et al., 2019). On a fresh weight basis, fish contains a good quantity of protein about $13-20 \%$ and contains all the essential amino acids. The fat content of fish ranges from 0.2 to $15 \%$ and it varies depending on the species as well as the season in general and fish has less fat than red meats. Fat from fish species contain the poly unsaturated fatty acids (PUFA) viz., EPA (eicosapentaenoic acid) and DHA (docosahexaenoic acid) are $\omega-3$ fatty acids which are essential for growth of children and prevents the occurrence of cardiovascular diseases such as coronary heart diseases (Calder, 2004). In pregnant women, the presence of PUFA in their diet helps in proper brain development among unborn babies and prevents preterm delivery and low birth weight (Mohanty et al., 2016 and Giri et al., 2010). Fish plays an important role in human nutrition as an efficient vehicle to deliver health promoting long chain $\omega-3$ polyunsaturated fatty acid (PUFA) in the diet (Sargent, 1997).

Micronutrients like vitamins and minerals are also present in the fish muscle. The micronutrients fulfil the hidden hunger of human population and prevent many disorders due to deficiency of such micronutrients (Mohanty et al., 2016a). Fish is soft, easy to cook, easily digestible than meat so young children can be fed fish as balanced diet with some cereals. The high nutritional value of fish is mainly related to their digestible protein which is an excellent source of EAA (Sanchez-Alonso, 2007). Fish protein occupies an important position in human nutrition (Nargis, 2006). FAO (2014) reported that a protein of $150 \mathrm{~g}$ of fish flesh can provide $50-60 \%$ of an adult's daily protein requirements.

Some information are available on nutrient composition of Indian major carp (Paul et al., 2015a, and 2016), catfish (Paul et al., 2015), air breathing fish (Paul et al., 2017), minor carps (Paul et al., 2018) and Freshwater fish (Paul et al., 2019). Keeping in view of importance of eating fish, the nutrient profile of four freshwater fish $(M$. vittatus, $C$. striata, $W$. attu and $P$. hypophthalmus) and one freshwater catfish $(O$. bimaculatus) were studied to document on protein, fat, minerals, vitamins, amino acids and fatty acids which will be helpful to dieticians, nutritionists, researchers, fish farmers and related stakeholders to promote fish as health food in human nutrition.

\section{MATERIALS AND METHOD:}

Collection of Samples: The samples were collected from various places of different states of India viz, West Bengal and Odisha. The weight and length ranges for the five different freshwater fish species were i.e. 5-25g and 7-14 cm for Mystus vittatus, 
20-200g and 15-30cm for Ompok bimaculatus, $150-850 \mathrm{~g}$ and $25-55 \mathrm{~cm}$ for Channa striata, 250-2000g and $35-65 \mathrm{~cm}$ for Wallago attu and 400-2000g and $30-60 \mathrm{~cm}$ for Pangasianodon hypophthalmus. The number of fish samples collected were viz., $M$. vittatus $(\mathrm{n}=59), O$. bimaculatus, $\mathrm{n}=52, C$. Striata, $\mathrm{n}=52, W$. Attu, $\mathrm{n}=48$ and $P$. hypophthalmus, $\mathrm{n}=56$. The sampling procedure and the sample preparation for analysis were done as per Sankar et al. (2010) and Paul et al. (2018)

\section{Proximate and mineral composition analysis:}

Proximate composition of fish tissue samples were done as per AOAC (1995). The mineral assay was done as per AOAC (2005) and Paul et al. (2014) using atomic absorption spectrophotometer (AAS) (Thermo Fisher, M Series). The energy content of fish samples were analysed by Bomb Caloric Method as per the AOAC (2005).

\section{Fatty acid analysis}

Pooled samples were extracted for fatty acid analysis following the method of Folch et al. (1957) using chloroform: methanol $(2: 1, \mathrm{v} / \mathrm{v})$ solvent system that contained $0.01 \%$ butylated hydroxyl anisole as an antioxidant. Fatty acid methyl esters (FAMEs) were prepared by the transmethylation with boron trifluoride in methanol from lipids fraction according to Metcalfe et al., (1996). The fatty acid methyl esters were quantified by injecting $1 \mu \mathrm{L}$ (50:1 split ratio) into a Gas Chromatograph (GC) (Perkin Elmer; CLARUS 480). The oven temperature was programmed from an initial temperature at $30^{\circ} \mathrm{C}$ rising to $140^{\circ} \mathrm{C}$ (hold time $4 \mathrm{~min}$.) and up to $200^{\circ} \mathrm{C}$. Nitrogen gas was used as a carrier gas. The injection port and the flame ionization detector were maintained at $260^{\circ} \mathrm{C}$ and $300^{\circ} \mathrm{C}$. GC operating software "Total Chrome" was followed. Identification of individual FA was identified by comparing with retention times to those of standards (SUPELCO, Cat.No. 47885-U) and quantified by comparing with respective areas.

\section{Amino Acid Analysis}

The amino acid analysis was done as per the method of Ishida et al. (1981). The amino acid samples were analysed from Edward Food Research and Analysis Centre Limited, Nilgunge, Kolkata- 700121(www.efrac.org) as per Paul et al. (2018).

\section{Vitamin analysis}

The fat soluble vitamins Retinol (Vitamin A), Cholecalciferol (Vitamin D) are assayed in High Performances Liquid Chromatography. Fish tissue (30g) was grinded with anhydrous sodium sulfate and extracted the oil using 2:1 chloroform: methanol after adding BHA as antioxidants (Folch et al., 1957).The sample preparation was done as per Sankar et al. (2010) and vitamin analysis was done in High Performance Liquid Chromatography from Edward Food Research and Analysis Centre Limited, Nilgunge, Kolkata- 700121 (www.efrac.org) as per Paul et al. (2018). 


\section{Statistical Analysis:}

The data were statistically analysed as per Snedecor and Cochran (1968) by one way ANOVA and the least significance difference (LSD) was used for comparison of the mean values. The data are presented as Mean \pm S.E.

\section{Results and Discussion}

The proximate compositions of the five freshwater fish are presented in table 1 . The moisture content was significantly $(\mathrm{P}<0.01)$ higher in C.striata vis-à-vis other fish species. The fat content was significantly $(\mathrm{P}<0.01)$ higher in $P$. hypophthalmus and M.vittatus compared to other fish species. Both protein and ash content of freshwater fish did not differ significantly among these fish.

Table 1. Proximate composition (\% as such basis) of five freshwater fish species

\begin{tabular}{l|l|l|l|l|l}
\hline Particulars & M. vittatus & O. bimaculatus & C. striata & W. attu & P. hypophthalmus \\
\hline Moisture** & $72.67^{\mathrm{a}} \pm 0.30$ & $75.17^{\mathrm{a}} \pm 0.34$ & $76.11^{\mathrm{b}} \pm 0.17$ & $74.25^{\mathrm{a}} \pm 0.42$ & $70.82^{\mathrm{a}} \pm 0.53$ \\
Protein & $14.94 \pm 0.20$ & $13.93 \pm 0.19$ & $14.46 \pm 0.21$ & $14.13 \pm 0.19$ & $15.41 \pm 0.29$ \\
Fat $^{* *}$ & $6.91^{\mathrm{bc}} \pm 0.18$ & $3.92^{\mathrm{a}} \pm 0.15$ & $2.09^{\mathrm{a}} \pm 0.09$ & $3.58^{\mathrm{a}} \pm 0.15$ & $7.17^{\mathrm{c}} \pm 0.39$ \\
Ash & $2.57 \pm 0.08$ & $2.12 \pm 0.05$ & $2.28 \pm 0.04$ & $1.97 \pm 0.05$ & $1.88 \pm 0.07$ \\
\hline
\end{tabular}

${ }^{a, b}, c$ Means bearing different superscripts in a row differ significantly $* *(\mathrm{P}<0.01)$

The moisture content of C.striata (76.11\%), O.bimaculatus (75.17\%) and W. attu $(74.25 \%)$ were similar to the moisture content of magur and singhi as reported by Paul et al. (2015); eel (M. armatus) reported by Pal and Ghosh (2013) and in A. mola, G. chapra and P. chola as reported by Mazumder et al. (2008). The moisture content of M.vittatus (72.67\%) and P.hypophthalmus (70.82\%) were lower than the earlier report. Paul et al. (2017) reported that the moisture content of Anabas testudineus $(68.00 \%)$ was lower than our findings. The protein content of these fish species in the present study was lower than the protein content of Anabas testudineus (16.91\%) as reported by Paul et al. (2017). The fat content of freshwater fish studies ranged from 2.09 to $7.17 \%$. There is an inverse relationship between moisture and lipid content of fish tissue (Wheeler and Morrissey, 2003 and Jankowska et al., 2007) also observed in fat and moisture content of M. vittatus and P. hypophthalmus. Our finding on fat contents were similar to magur and singhi (Paul et al., 2015), small indigenous fish species of Bangladesh (Mazumder, 2008), freshwater eel (Pal and Ghosh, 2013) and Anabas testudineus (Paul et al., 2017).

The ash content of five freshwater fish as studied ranged from 1.88 to $2.57 \%$. Our results were in agreement with earlier reports (Mazumder et al., 2008, Paul et al., 2015, Bogard et al., 2015 and Chrisolite et al., 2015). The protein and ash content of $P$. hypophthalmus was similar to Thai pangas whereas fat content was lower and moisture content was higher than Thai pangas in the present work as reported 
elsewhere (Bogard et al., 2015). The fat (9.5\%) and protein content was higher in modhu pabda compared to our data protein and fat; but ash content $(2.12 \%)$ was higher $(16.20 \%)$ than the modhu pabda $(0.90 \%)$ as reported by Bogard et al. (2015). The fat and ash content of $C$. striata was higher than shoal but protein content $(14.46 \%)$ was lower than shoal $(18.70 \%)$ as reported earlier (Bogard et al., 2015). However the protein content of $C$. striata of our finding was similar to protein content of C.stiata (Chrisolite et al., 2015). The protein and ash content of $M$. vittatus was similar to tengra whereas fat and moisture content was higher in tengra in comparison to our findings in M. vittatus (Bogard et al., 2015).

The total crude protein content of five freshwater fish species ranged from 13.93 to 15.41 (\% as fresh basis); which seems to be of high dietary quality, being an animal sourced protein (WHO, 2007). Fat varies to a great extent compared to other proximate component of fish and it reflects the differences in the way fat is stored in particular species. It may also vary due to seasonal/lifecycle variations and the diet/food availability of the species at the time of sampling (Ababouch, 2005).

The mineral content of these five species is presented in table 2. Perusal of data showed Potassium content was significantly $(\mathrm{P}<0.01)$ higher in C.striata and P.hypophthalmus. The manganese content was significantly $(\mathrm{P}<0.01)$ higher in $P$. hypophthalmus. The sodium, iron, copper and zinc content did not differ significantly among the fish species. The Calcium content is presented in figure 2. The Calcium content was maximum in M.vittatus and followed by O.bimaculatus, W. attu and $P$. hypophthalmus. The sodium, potassium, iron, copper, zinc and manganese content of all species are shown in (Table 2). Sodium content varied considerably with a range from 36.66 to 51.65 ( $\mathrm{ppm}$ ). The sodium content of five fresh water fish was lower than the value as reported in magur and singhi (Paul et al., 2015). The sodium content of P. Sutchi (99.40ppm) was higher than the value reported in P. hypophthalmus (Chrisolite et al., 2015); whereas sodium content of $M$. vittatus in our study was higher than the value of M. oar as reported elsewhere (Chrisolite et al., 2015). The potassium content of the five freshwater fish was lower than the value in M. oar and P. sutchi (Chrisolite et al., 2015) and also in singhi and magur (Paul et al., 2015). The iron content of five freshwater fish ranged from 0.46 to 0.67 (ppm). The iron content of $O$. bimaculatus $(0.46 \mathrm{ppm})$ was higher than the iron value of $O$. bimaculatus $(0.16)$ as reported by Ghosh et al. (2004). The iron content of $M$. vittatus and $P$. hypophthalmus were higher than the iron content of $M$. oar and $P$. Sutchi respectively as reported earlier (Chrisolite et al., 2015). The copper content ranged from 0.24 to 0.68 (ppm) in the fish species (table 2). Our results were in agreement with the copper content of $O$. bimaculatus with the modhu pabda. The copper content of $C$. striata was higher than the copper content of Shoal and the copper content of $P$. hypophthalmus was lower than Majhari Thai pangas are reported by Bogard et al. (2015). The zinc content of $O$. bimaculatus was higher than the earlier report of zinc content of $O$. bimaculatus (Ghosh et al., 2004) and modhu pabda (Bogard et al., 2015). However, the zinc content of $M$. vittatus and $W$. attu were lower than the zinc 
content of Mystus spp. and W. attu as reported earlier (Chari et al., 2000). Our results on zinc content of freshwater fish were lower than the zinc content of singhi and magur (Paul et al., 2015). The manganese contents of fish in the present study were lower than the earlier reports (Paul et al., 2015 and Chari et al., 2000). The calcium content of five freshwater fish ranged from 150 to $255\left(\mathrm{mg} 100^{-1}\right)$. Our results were higher than the value of modhu pabda shoal and Thai pangas (Bogard et al., 2015); W. attu and Mystus spp. as reported by Chari et al. (2000). However, our results were in agreement with the calcium content of singhi and magur (Paul et al., 2016).

Table 2. Mineral content ( $\mathrm{ppm}$ ) of five freshwater fish species

\begin{tabular}{lllllll}
\hline Particulars & M. vittatus & O. bimaculatus & C. striata & W. attu & P. hypophthalmus \\
\hline Sodium & $36.92 \pm 5.24$ & $47.70 \pm 2.74$ & $39.66 \pm 5.30$ & $51.58 \pm 6.25$ & $51.65 \pm 3.88$ \\
Potassium** & $70.48^{\mathrm{a}} \pm 16.14$ & $126.55^{\mathrm{b}} \pm 6.13$ & $170.60^{\mathrm{c}} \pm 4.95$ & $112.10^{\mathrm{b}} \pm 5.10$ & $129.33^{\mathrm{bc}} \pm 7.33$ \\
Iron & $0.67 \pm 0.06$ & $0.46 \pm 0.05$ & $0.54 \pm 0.06$ & $0.50 \pm 0.04$ & $0.47 \pm 0.03$ \\
Copper & $0.38 \pm 0.07$ & $0.24 \pm 0.06$ & $0.56 \pm 0.07$ & $0.68 \pm 0.11$ & $0.43 \pm 0.06$ \\
Zinc & $0.54 \pm 0.03$ & $0.68 \pm 0.07$ & $0.49 \pm 0.06$ & $0.38 \pm 0.02$ & $0.49 \pm 0.06$ \\
Manganese*** & $0.08^{\mathrm{a}} \pm 0.01$ & $0.17^{\mathrm{ab}} \pm 0.02$ & $0.19^{\mathrm{ab}} \pm 0.02$ & $0.11^{\mathrm{ab}} \pm 0.02$ & $0.21^{\mathrm{b}} \pm 0.04$ \\
\hline
\end{tabular}

a, b, c Means bearing different superscripts in a row differ significantly** $(\mathrm{P}<0.01)$

The fatty acid profile of five freshwater species are presented in table 3.The total saturated fatty acid (SFA) was significantly $(\mathrm{P}<0.01)$ higher in Mystus vittatus and followed by $W$. attu, C. striata and $O$. bimaculatus. The predominant SFA was palmitic acid which was significantly higher in $M$. vittatus and followed by $C$. striata. Another SFA stearic acid was significantly higher in W. attu and P. hypophthalmus. The total mono unsaturated fatty acid (MUFA) was significantly higher in $P$. hypopthalmus and followed by $C$. striata and $W$. attu. Oleic acid, a predominant MUFA was significantly $(\mathrm{P}<0.01)$ higher in $P$. hypophthalmus, $W$. attu and $C$. striata. Other MUFAs like myristoleic acid, pentadecenoic acid, palmitoleic acid and erucic acid also differed significantly $(\mathrm{P}<0.01)$ among the five fish groups.

The polyunsaturated fatty acids (PUFA) are one of the key fatty acids which are important from human health point of view. The linolenic acid was significantly $(\mathrm{P}<0.01)$ higher in $P$. hypophthalmus and $O$. bimaculatus. The $\gamma$-Linolenic acid was significantly $(\mathrm{P}<0.05)$ higher in $W$. attu. Another important as well as predominant PUFA, docosahexaenoic acid was significantly $(\mathrm{P}<0.05)$ higher in $C$. striata and $O$. bimaculatus. The total $\omega 3$ fatty acid was significantly $(\mathrm{P}<0.05)$ higher in $O$. bimaculatus, P. hypophthalmus and C.striata. The other fatty acids viz., EPA, arachidonic acid, eicosatrienoic acid, eicosadienoic acid, $\alpha$ Linolenic acid and Linolelaidic acid did not differ significantly among the fish species. 
Table 3. Fatty acid profile ( $\%$ of total fatty acid) of five freshwater fish species

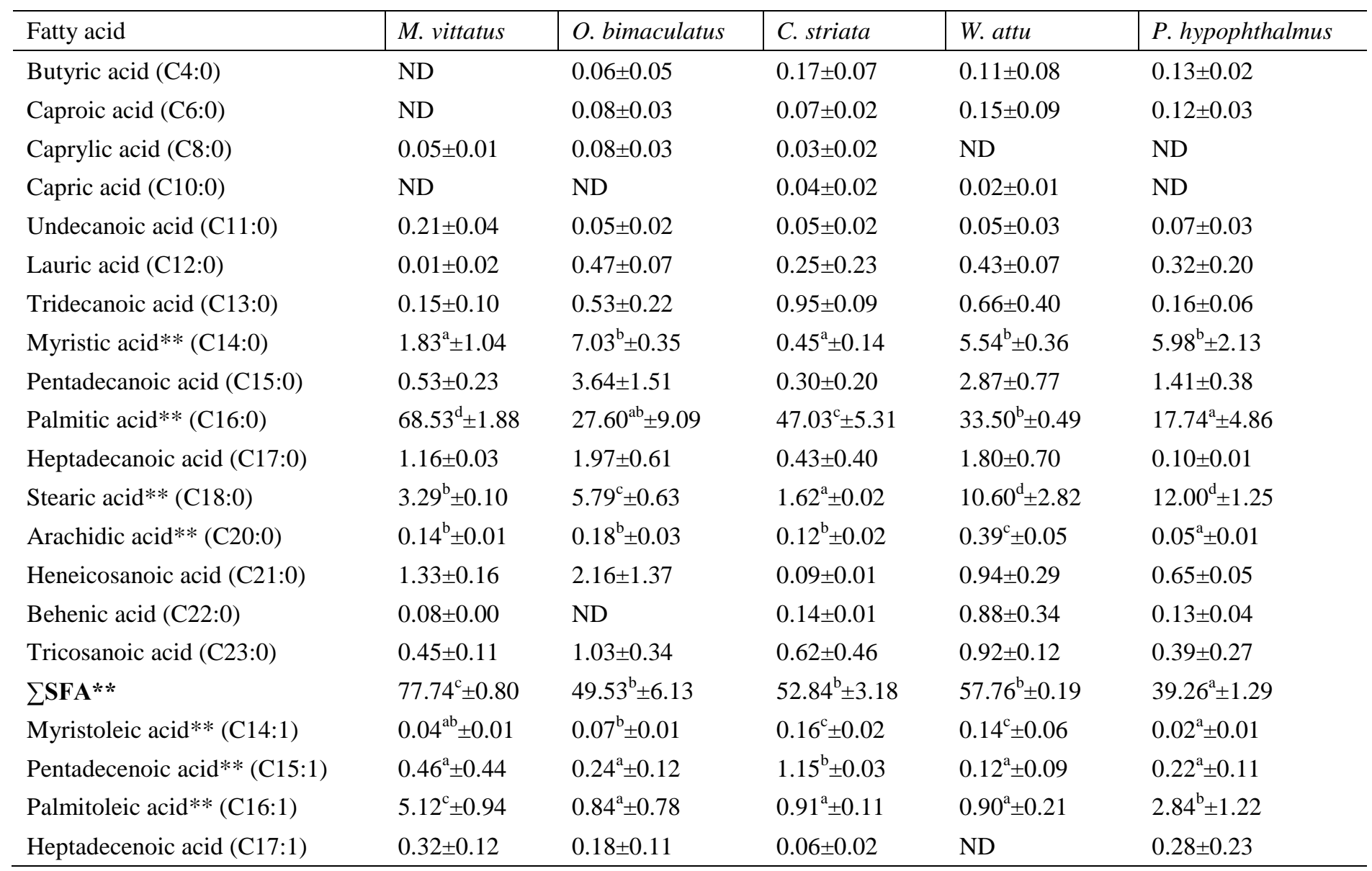




\begin{tabular}{|c|c|c|c|c|c|}
\hline Fatty acid & M. vittatus & O. bimaculatus & C. striata & W. attu & P. hypophthalmus \\
\hline Oleic acid** $(\mathrm{C} 18: 1 \mathrm{n} 9 \mathrm{c})$ & $6.03^{\mathrm{a}} \pm 1.55$ & $18.95^{\mathrm{b}} \pm 0.92$ & $28.81^{\mathrm{c}} \pm 1.11$ & $26.30^{c} \pm 3.77$ & $34.12^{\mathrm{d}} \pm 1.05$ \\
\hline Elaidic acid $(\mathrm{C} 18: \ln 9 \mathrm{t})$ & ND & $2.98 \pm 0.00$ & ND & ND & ND \\
\hline Eicosanoic acid $(\mathrm{C} 20: \ln 9 \mathrm{c})$ & $0.32 \pm 0.03$ & $1.42 \pm 0.31$ & $0.13 \pm 0.005$ & $1.28 \pm 0.07$ & $0.88 \pm 0.59$ \\
\hline Erucic acid** (C22:1n9) & $0.20^{\mathrm{a}} \pm 0.00$ & $1.04^{\mathrm{d}} \pm 0.07$ & $0.48^{\mathrm{b}} \pm 08$ & ND & $0.87^{\mathrm{cd}} \pm 0.15$ \\
\hline$\sum$ MUFA** & $12.09^{\mathrm{a}} \pm 1.19$ & $22.97^{\mathrm{b}} \pm 2.05$ & $31.69^{\mathrm{c}} \pm 1.14$ & $28.64^{\mathrm{c}} \pm 3.98$ & $39.21^{\mathrm{d}} \pm 0.94$ \\
\hline Linolelaidic acid (C18:2n6t) & $0.07 \pm 0.02$ & $0.10 \pm 0.03$ & $0.11 \pm 0.04$ & $0.13 \pm 0.03$ & $0.03 \pm 0.02$ \\
\hline Linoleic acid* $(\mathrm{C} 18: 2 \mathrm{n} 6 \mathrm{c})$ & $2.75^{\mathrm{a}} \pm 0.18$ & $8.24^{\mathrm{bc}} \pm 2.11$ & $1.39^{\mathrm{a}} \pm 0.15$ & $5.77^{\mathrm{b}} \pm 1.34$ & $10.30^{c} \pm 3.11$ \\
\hline$\gamma$-Linolenic acid* $(\mathrm{C} 18: 3 \mathrm{n} 6)$ & $0.29^{\mathrm{bc}} \pm 0.12$ & $0.35^{\mathrm{cd}} \pm 0.05$ & $0.07^{\mathrm{a}} \pm 0.03$ & $0.55^{\mathrm{d}} \pm 0.05$ & $0.12^{\mathrm{a}} \pm 0.04$ \\
\hline$\alpha$ Linolenic acid (C18:3n3) & $3.52 \pm 1.71$ & $8.67 \pm 2.40$ & $1.40 \pm 0.98$ & $1.32 \pm 0.32$ & $4.95 \pm 2.85$ \\
\hline Eicosadienoic acid (C20:2) & $0.29 \pm 0.06$ & $1.72 \pm 1.20$ & $0.24 \pm 0.15$ & $0.19 \pm 0.04$ & $0.47 \pm 0.24$ \\
\hline Eicosatrienoic acid (C20:3n6) & $0.28 \pm 0.07$ & $0.69 \pm 0.04$ & $1.24 \pm 0.15$ & $0.54 \pm 0.26$ & $1.40 \pm 0.19$ \\
\hline Eicosatrienoic acid (C20:3n3) & ND & $1.08 \pm 0.45$ & $0.40 \pm 0.09$ & $0.85 \pm 0.50$ & $0.31 \pm 0.02$ \\
\hline Arachidonic acid (C20:4n6) & $0.24 \pm 0.02$ & $3.52 \pm 0.23$ & $1.6 \pm 0.55$ & $1.08 \pm 0.93$ & $1.49 \pm 0.44$ \\
\hline $\begin{array}{l}\text { Eicosapentaenoic acid or EPA } \\
\text { (C20:5n3) }\end{array}$ & $1.61 \pm 0.51$ & $0.13 \pm 0.03$ & $4.81 \pm 0.46$ & $2.80 \pm 2.51$ & $1.54 \pm 0.56$ \\
\hline $\begin{array}{l}\text { Docosahexaenoic acid or DHA* } \\
\text { (C22:6n3) }\end{array}$ & $2.30^{\mathrm{b}} \pm 0.18$ & $4.80^{\mathrm{c}} \pm 1.87$ & $4.78^{c} \pm 1.15$ & $0.31^{\mathrm{a}} \pm 0.15$ & $1.31^{\mathrm{a}} \pm 0.33$ \\
\hline$\sum$ PUFA* & $9.98^{\mathrm{a}} \pm 1.30$ & $27.49^{\mathrm{c}} \pm 4.34$ & $15.51^{\mathrm{ab}} \pm 4.32$ & $13.61^{\mathrm{a}} \pm 3.98$ & $21.59^{\mathrm{bc}} \pm 0.31$ \\
\hline$\omega 3: \omega 6$ & $1.72 \pm 0.48$ & $1.70 \pm 0.58$ & $2.41 \pm 0.32$ & $0.46 \pm 0.13$ & $0.59 \pm 0.46$ \\
\hline$\sum \omega 3^{*}$ & $6.26^{\mathrm{a}} \pm 1.45$ & $15.76^{\mathrm{c}} \pm 0.88$ & $11.33^{\mathrm{bc}} \pm 3.78$ & $4.31^{\mathrm{a}} \pm 2.22$ & $14.80^{\mathrm{c}} \pm 4.09$ \\
\hline$\sum \omega 6$ & $3.72 \pm 0.15$ & $11.73 \pm 3.74$ & $4.61 \pm 1.16$ & $8.65 \pm 2.42$ & $6.79 \pm 4.39$ \\
\hline
\end{tabular}

a, b, c, d Means bearing different superscripts in a row differ significantly* $(\mathrm{P}<0.05)$; $* *(\mathrm{P}<0.01)$, ND: Not detected, SFA- Saturated Fatty Acid, MUFA- Mono Unsaturated Fatty Acid, PUFA- Poly Unsaturated Fatty Acid 
The fatty acid content of fish varies due to species, sex, size and other external factors like feed, temperature, salinity, geographical locations and general rearing condition (Sener et al., 2005). Kamler et al. (2001) reported that fatty acid in fish is derived from diet and its biosynthesis. The oleic acid was predominant MUFA and it was maximum in $P$. hypophthalmus. The oleic acid content of $W$. attu was similar to the oleic acid content of mrigal of size 501-2000g as reported by Paul et al. (2015). The PUFA content Mystus, Ompok, Channa, Wallago and Pangas were less than the SFA content. This result was in agreement with the earlier report in Indian Major Carp (Paul et al., 2015) and Koi (Paul et al., 2017). The hypothesis that the freshwater fish contains low PUFA as their feed is largely based on plant materials (Vlieg and Body, 1988). The PUFA content was maximum in O. bimaculatus (27.49\%) which was in agreement with PUFA content of Catla of size 51-500g as reported earlier (Paul et al., 2015). Fish oils are rich in $\omega-3$ fatty acids. The docosahexaenoic acid (DHA) content ranged from 0.31 to $4.78 \%$ and maximum in Channa; which was in agreement with DHA content of catla of size 501-2000g and rohu of size $>2000 \mathrm{~g}$ as reported by Paul et al. (2015). The Eicosapentaenoic acid was also maximum in $C$. striata $(4.81 \%)$. The $\omega-3$ fatty acids viz., DHA and EPA are essential and important fatty acids that enhance quality of life and lower the risk of premature death (Mohanty et al., 2016). DHA is proven to be essential to pre and post natal brain development whereas EPA influences mood and behaviour (Kidd, 2007). Consumption of fish and fish oils containing $\omega-3$ fatty acids prevents cardio vascular diseases, arthritis, psoriasis etc (Kris-Etherton and Haris, 2002 and Giri et al., 2010). Freshwater fish species are also known to contain high amount of EPA and DHA (Wang et al., 1990).

The chain length varies from $\mathrm{C} 14$ to $\mathrm{C} 20$ of varying degree of unsaturation from saturated to poly unsaturated (Swapna et al., 2010). The different classes of fatty acids are saturated fatty acids (SFA), mono unsaturated fatty acids (MUFA) and poly unsaturated fatty acids (PUFA). Among the saturated fatty acids the palmitic acid was predominant which was in agreement with earlier reports (Paul et al., 2015, 2017 and Jakhar et al., 2012). The total SFA content of $M$. vittatus (77.74\%) was maximum among other fish species and this content was similar to that of Rohu (Paul et al., 2015). The palmitic acid is considered to be as key to many metabolic processes in fish and other aquatic animals (Ackman and Eaton, 1966). The myristic acid was high in $O$. bimaculatus (7.03\%). The myristic acid is used as flavouring agents in food items (Burdock et al., 2007). The tasty flavour of O. bimaculatus could be due to high content of myristic acid present in it. The MUFA content of $P$. hypophthalmus was similar to rohu, catla and magur as reported earlier (Paul et al., 2015, 2016).

The energy content of five freshwater fish species are presented in figure 5 . The gross energy content was maximum in $P$. hypophthalmus, $W$. Attu and $O$. bimaculatus. The

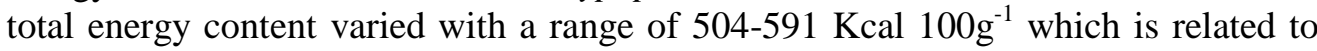
the variation in fat content of freshwater fish and our result was higher than the 
B.N. Paul et al.

earlier reports (Schreckenbach et al., 2001, Chrisolite et al., 2015 and Bogard et al., 2015).

The vitamin A and D content (I.U. $100 \mathrm{~g}^{-1}$ ) are presented in figure 1. Vitamin A content was maximum in $O$. bimaculatus and followed by $M$. vittatus whereas the vitamin D content was higher in M. Vittatus and $C$. Striata vis-à-vis other freshwater fish. Vitamin A content of these five fish ranged from 5.0-1058.0 (I.U $100 \mathrm{~g}^{-1}$ ). The vitamin A content was maximum in $O$. bimaculatus and was higher than the vitamin A content of A. testudineus (Paul et al., 2017). Our data on vitamin A content of five freshwater fish was higher than the vitamin A content of some important fish of Bangladesh (Bogard et al., 2015). Liu (2003) reported that vitamin content from fish is readily available to the body compared to plant sources. Vitamin A plays a vital role for normal vision and bone growth; its derivative retinoic acid regulates gene expression in the development of epithelial tissue (Roos et al., 2003). The vitamin D content ranged from 5.0 to 384.0 (IU $100 \mathrm{~g}^{-1}$ ). The vitamin D activate the innate immune system whereas dampen the adaptive immune system (Hewison, 2011); in addition to its role in bone development. Vitamin D content of $M$. vittatus was higher than the vitamin D content of A. testudineus (Paul et al., 2017). The vitamin D is also higher than the freshwater fish as reported by Bogard et al. (2015). Our data on vitamin A content of fish was higher than the vitamin A content of some important fish of Bangladesh (Bogard et al., 2015).

The essential amino acid content is presented in figure 3, where the Arginine, Threonine and Isoleucine were more in P. hypophthalmus. The histidine content was high in $P$. hypophthalmus and followed by M. vittatus and $O$. bimaculatus. The tryptophan was higher in $C$. striata and $W$. attu as depicted in figure 3.The Non Essential Amino Acid is presented in table 4. The Glutamic acid was more in $O$. bimaculatus and M. vittatus.

Figure 3 and 4 show the amino acid composition of the fish muscle of five freshwater fish species. Fish muscle is known to contain balanced amino acid composition (Venugopal et al., 1996 and Mohanty et al., 2014). Among the fish species Arginine, Histidine and Isoleucine were in higher amount in $P$. hypophthalmus vis-à-vis other fish species. Arginine plays an important role in wound healing, immune function, cell division, ammonia removal and hormone release. It is also the precursor for the biological synthesis of nitric oxide which plays an important role in neurotransmission, blood clotting and maintenance of blood pressure (Mohanty et al., 2014). The arginine content in P. hypophthalmus was similar to A. testudineus as reported by Mohanty et al., (2014). The histidine content in P. hypophthalmus was similar to C. mrigala, S. weitei, S. commersonii as reported earlier (Mohanty et al., 2014). Histidine is needed for growth and repair of tissue, for maintenance of myelin sheaths (Heimann, 1992). Histidine content was also rich in M. vittatus and $O$. bimaculatus. Isoleucine content of $P$. hypophthalmus was lower than the isoleucine content of other food fishes reported earlier (Mohanty et al., 2014). 
Tryptophan is a precursor for serotonin, a neurotransmitter. Free tryptophan enters the brain cells to form serotonin. The tryptophan content of C. reba and W. Attu were similar to $S$. waitei and S. Commersonii as reported elsewhere (Mohanty et al., 2014). The glutamic acid content of $M$. vittatus and $O$. bimaculatus was lower than $H$. fossilis and C. batrachus as reported by Mohanty et al. (2014). Glutamic acid plays an important role in transmission reactions and required for key molecules viz., glutathione, required for removal of toxic peroxide and the poly glutamate folate cofactors. The Aspartic acid was maximum in C. striata and followed by W. attu and $M$. vittatus. Another NEAA glutamine was higher in $M$. vittatus and $O$. bimaculatus. The Asparagine was more in W. attu and C. striata.

The amino acid contents vary from fish species to species. Therefore, in general, arginine, histidine and isoleucine were rich in $P$. hypophthalmus. Tryptophan, asparagine and glutamine content were higher in $C$. Striata and W. attu. Aspartic acid was rich in $C$. striata and glutamic acid was rich in $O$. bimaculatus.

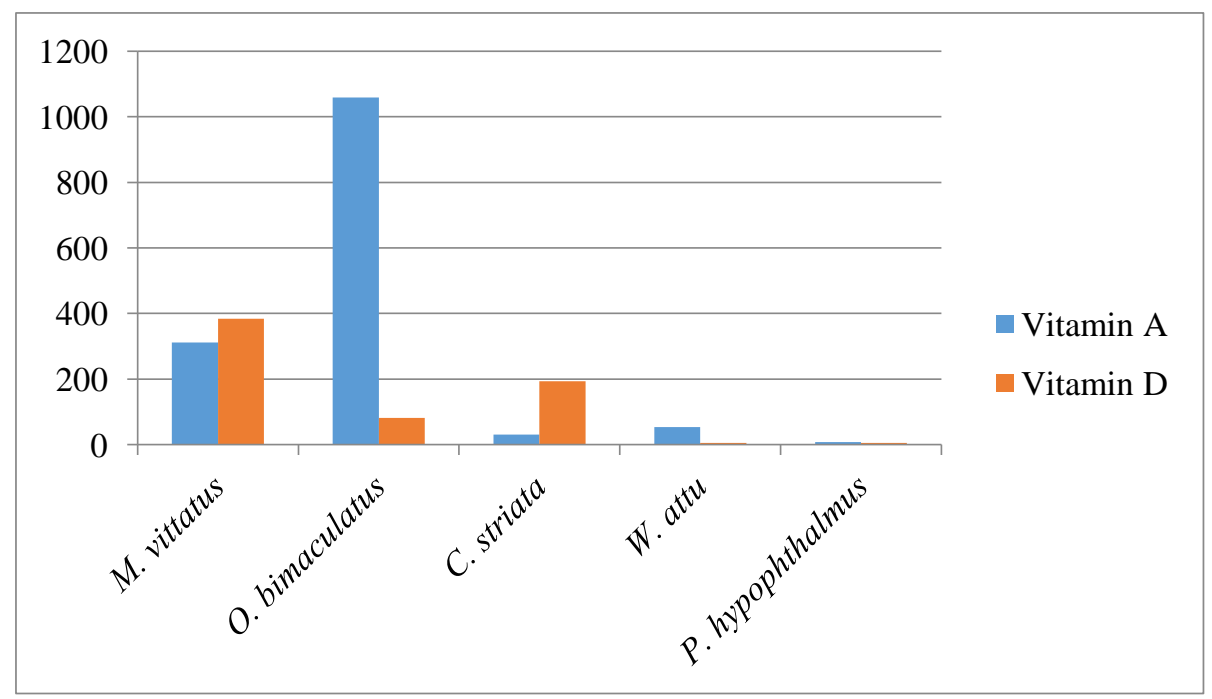

Figure 1. Vitamin A and D content (IU $100 \mathrm{~g}^{-1}$ ) of five freshwater fish species 


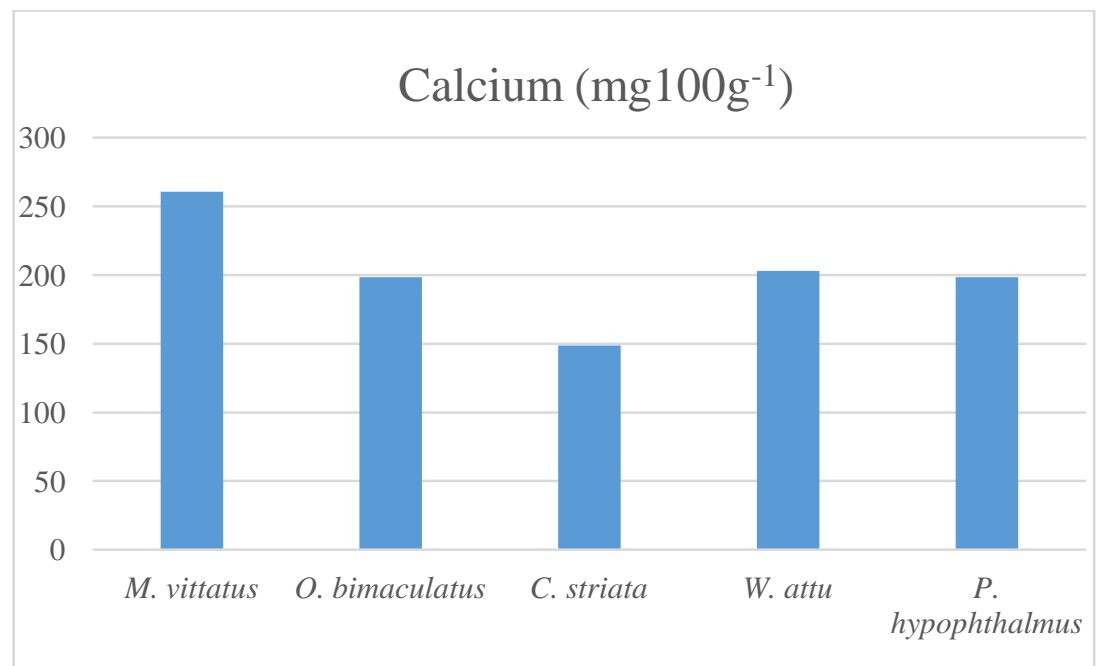

Figure 2: Calcium content $\left(\mathrm{mg} 100 \mathrm{~g}^{-1}\right)$ of five freshwater fish species

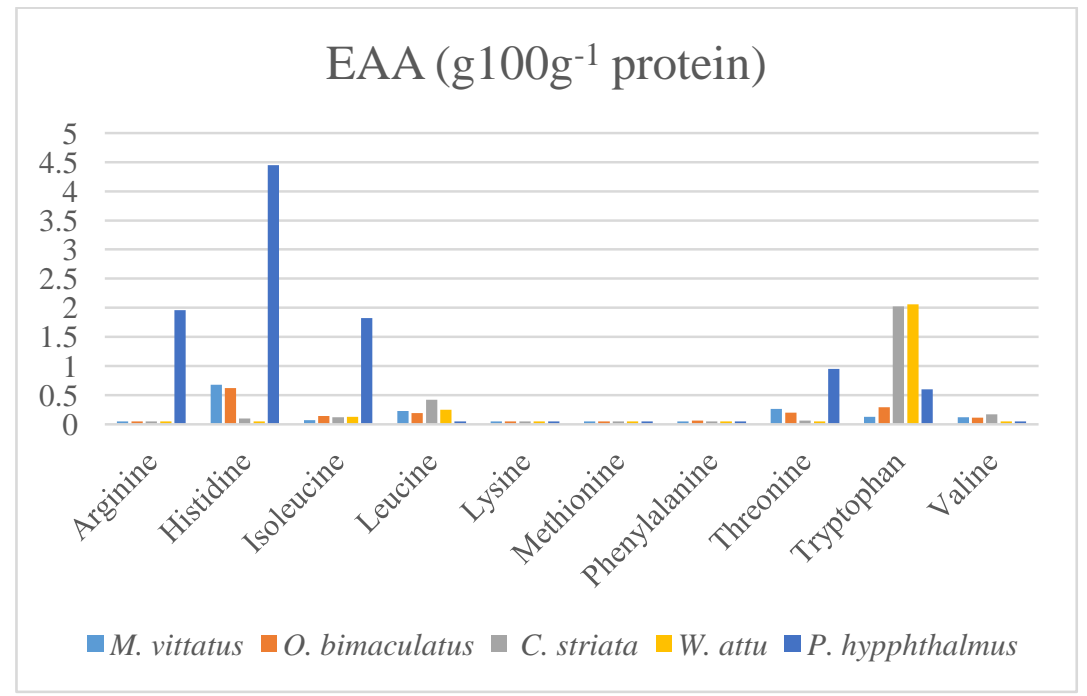

Figure 3. Essential Amino Acid composition (g $100 \mathrm{~g}^{-1}$ protein) of five freshwater fish species 


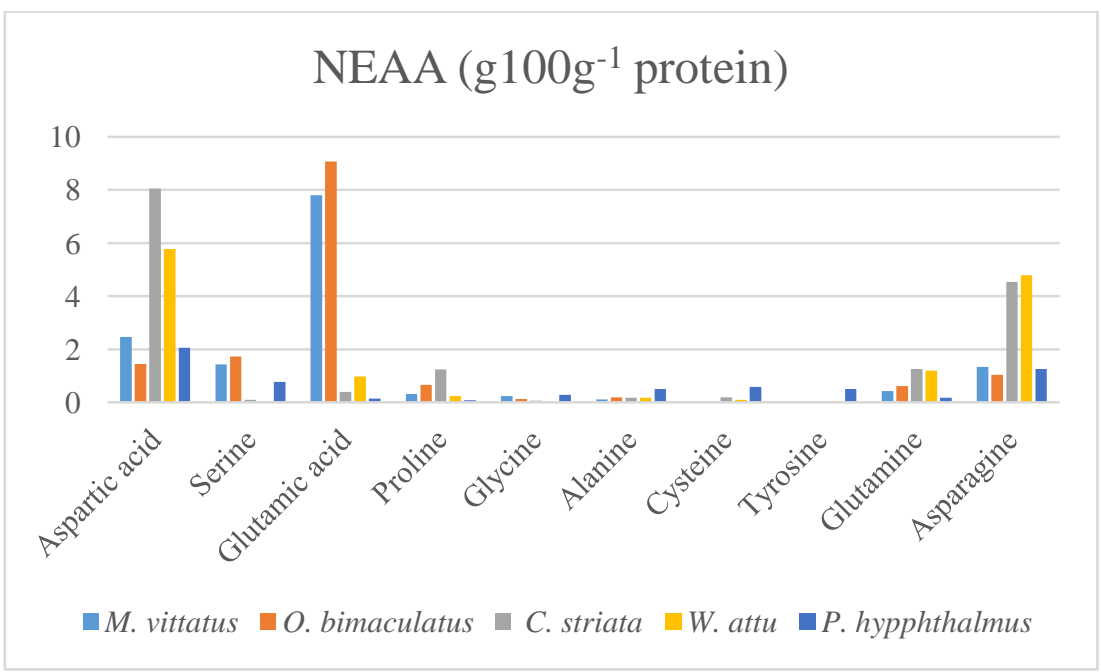

Figure 4. Non-Essential Amino Acid composition (g $100 \mathrm{~g}^{-1}$ protein) of five freshwater fish species

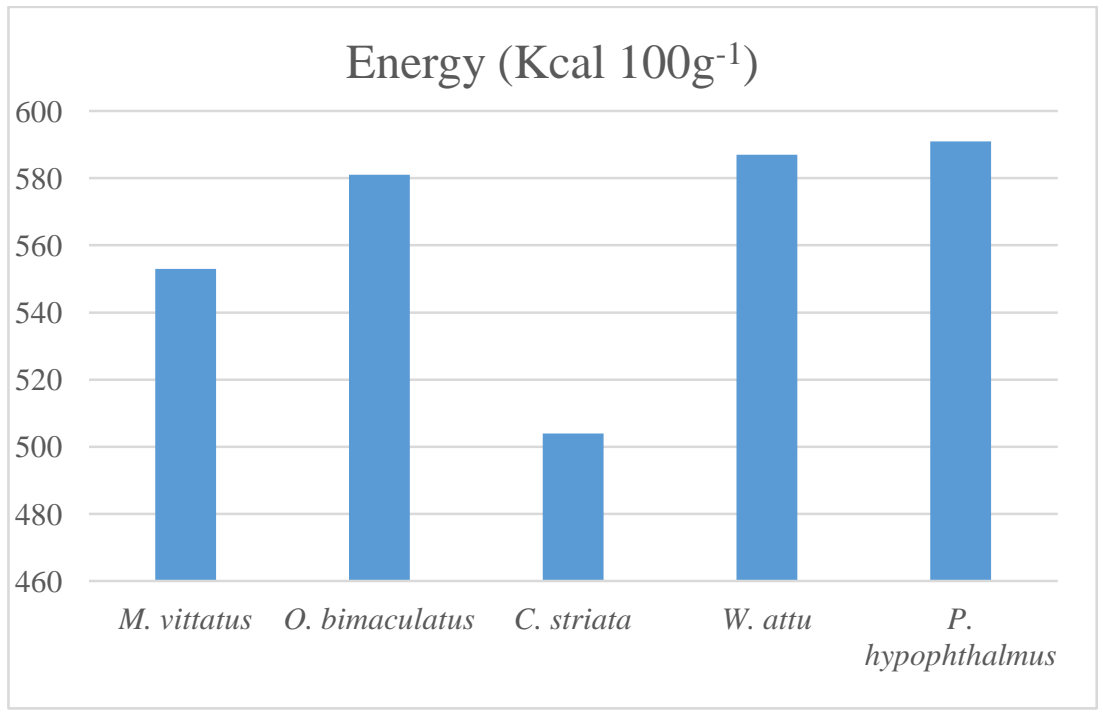

Figure 5. Energy content (Kcal $100 \mathrm{~g}^{-1}$ ) of five freshwater fish 
B.N. Paul et al.

\section{CONCLUSION}

The nutrient profile of five freshwater fish species viz., Mystus vittatus, Ompok bimaculatus, Channa striata, Wallago attu and Pangasianodon hypophthalmus revealed that they are rich in protein, fat, ash, energy, minerals, vitamins, amino acid and fatty acid contents which are required for human health. The important fatty acids eicosapentaenoic acid and docosahexaenoic acid are present in these fish species. Arginine, threonine, isoleucine, histidine contents are rich in $P$. hypophthalmus. The vitamin A and D content are higher in $O$. bimaculatus and $M$. vittatus respectively. The obtained data on the nutrient profile of fish will help the nutritionists, researchers, medical practitioners, dieticians and other related stakeholders to advise consumers to take fish as health food.

\section{ACKNOWLEDGEMENT}

This work was supported by Ministry of Agriculture and Farmers Welfare, Government of India under ICAR Outreach Activity on Nutrient Profiling and Evaluation of fish as a Dietary component. The authors greatly acknowledge the help of DDG (Fy, ICAR) and Director, ICAR-CIFA for providing necessary support and facility to conduct the work. The help extended by Mrs. Puja Singh during analysis of samples is duly acknowledged.

\section{REFERENCES}

Ababouch, L. (2005). Lipids. FAO Fisheries and Aquaculture Department, Rome, Italy. http://www.fao.org/fishery/topic/14826/en.

Ackman, R.G., and Eaton, C.A. (1966). Some commercial Atlantic herring oils; Fatty acid composition. Journal of Fisheries Research Board of Canada, 23: 991-1006

AOAC. (1995). Official Methods of Analysis, $16^{\text {th }}$ ed. Association of Official Analytical Chemists, Washington, DC

AOAC. (2005). Official Methods of Analysis, $18^{\text {th }}$ ed. Association of Official Analytical Chemists, Washington, DC

Bene, C., Macfayden, G., and Allison, E.H. (2007). Increasing the contribution of small-scale fisheries to poverty alleviation and food security. FAO Fisheries Technical Paper no. 481, FAO, Rome

Bogard, J.R., Thilsted, S.H., Marks, G.C., Wahab, M.A., Hossain, M.A.R., Jakobsen, J., and Stangoulis, J. (2015). Nutrient composition of important fish species in Bangladesh and potential contribution to recommended nutrient intakes. Journal of Food Composition and Analysis, 42: 120-133

Burdock, G.A., and Carabin, I.G. (2007). Safety assessment of myristic acid as a food ingredient. Food and Chemical Technology, 45: 517-529

Calder, P.C. (2004). Long chain fatty acids and cardiovascular disease: further evidence and insights. Nutrition Research, 24: 761-772 
Chari, M.S., Jain, R.K.,Tiwari, S.P., and Rajagopal, S. (2000). Body composition and mineral status of some common fish varieties from village ponds. Indian Journal of Animal Science, 70: 434-435

Chrisolite, B., Shanmugam, S.A., and Arumugam, S.S. (2015). Proximate and mineral composition of fifteen freshwater fishes of Toothukudi, Tamilnadu. Journal of Aquaculture in the Tropics, 30(1-2) : 33-43

FAO. (2014). The State of World Fisheries and Aquaculture. (2014). Food and Agriculture Organization of the United Nations, Rome

Folch, J., Less, M., and Stanley, G.H.S. (1957). A simple method for the isolation and purification of total lipids from animal tissues. Journal of Biochemistry, 226: 497-509

Ghosh, D., Chakraborty, R., and Dey, S. (2004). Nutritive value of some fishes available in the markets of a northeast Indian city, Shillong, with reference to certain essential elements. Journal of Inland Fishery Society of India, 36(1): 36-40

Giri, S.S., Paul, B.N., Sahoo, S.K., Rangacharyulu, P.V., Rath, S.C., and Mohanty, S.N. (2010). Fish oils and cardio vascular health. Fishing Chimes, 30(2): 37-39

Heimann, W. (1982). Fundamental of Food Chemistry, AVI Publishing Company, Westport, Conn, USA.

Hewison, M. (2011). Vitamin D and innate and adaptive immunity. Vitamin and Hormones, 86: 23-62

Ishida, Y., Fujita, T., and Asai, K. (1981). New detection and separation method for amino acids by high-performance liquid chromatography. Journal of Chromatography, 204: $143-148$

Jakhar, J.K., Pal, A.K., Reddy, A.D. Sahu, N.P., Venkateshwarlu, G., and Vardia, H.K. (2012). Fatty acid composition of some selected Indian fishes. African Journal of Basic and Applied Sciences, 4(5):155-160

Jankowska, B., Zakes, Z., Zmijewski, T., Szczepkowski, M., and Kowalska, A. (2007). Slaughter yield, proximate composition, and flesh colour of cultivated and wild perch (Perca fluviatilis L.). Food Chemistry, 118: 764-768.

Kamler, E.B., Krasicka, S. and Rakusa-Suszczewski. (2001). Comparison of lipid content and fatty acid composition in muscle and liver of two Notothenioid fishes from Admiralty Bay (Antartica): An eco-physiological perspective. Polar Biology, 24,:735-743

Kidd, P.M. (2007). Omega-3 DHA and EPA for cognition, behavior and mood. Clinical findings and structural-functional synergies with cell membrane phospholipids. Alternative Medicine Review, 12: 207-227

Kris-Etherton, P.M., and Harris, W.S. (2002). Fish consumption, Fish oil, Omega 3-fatty acids and cardiovascular disease. Circulation, 106: 2747-2757

Liu, R.H. (2003). Health benefits of fruit and vegetables are from additive and synergistic combinations of phytochemicals. American Journal of Clinical Nutrition, 78(suppl), 517S-520S

Mazumder, M.S.A., Rahman, M.M., Ahmed, A.T.A., Begum, M., and Hossain, M.A. (2008). Proximate Composition of Some Small Indigenous Fish Species (SIFS) in Bangladesh. International Journal Sustainable Crop Production, 3(3):18-23 
Metcalfe, L.D., Schmitz, A.A., and Petha, J.R. (1996). Rapid preparation of fatty acid esters from lipids for gas chromatographic analysis. Analytical Chemistry, 38: 514-515

Mohanty, B.P., Ganguly, S., Mahanty, A., Mitra, T., Patra, S., Karunakaran, D., Mathew, S., Chakraborty, K., Paul, B.N., Sarma, D., Dayal, S., Singh, S., and Ayyappan, S. (2019). Fish in Human Health and Nutrition. p 189-218. In B.P. Mohanty (ed.) Advances in Fish Research, Narendra Publishing House, New Delhi,

Mohanty, B.P., Sankar, T.V., Ganguly, S., Mahanty, A., Anandan, R. Chakraborty, K., Paul, B.N., Sarma, D., Dayal, J., Venkateshwarlu, G., Mathew, S., Asha, K.K., Mitra, T., Karunakaran, D., Chanda, S., Shahi, N., Das, P., Das P., Akhtar, M.S., Vijayagopal, P., and Sridhar, N. (2016a). Micronutrient composition of 35 food fishes from India and their significance in human nutrition. Biological Trace Element Research, 174 (2), 448-458. DOI 10.1007/s12011-016-0714-3

Mohanty, B.P., Ganguly,S., Mahanty,A., Sankar, T.V., Anandan, R. Chakraborty, K., Paul, B.N., Sarma, D., Dayal, J.S., Venkateshwarlu, G., Mathew, S., Asha, K.K., Karunakaran, D., Mitra, T., Banerjee, S., Chanda, S., Shahi, N., Das, P., Das P., Akhtar, M.S., Vijayagopal, P., and Sridhar, N. (2016). DHA, EPA content and Fatty acid Profile of 39 Food Fishes from India. Biomedical Research International, pp.1-14. Doi./org/10.1155/2016/4027437

Mohanty, B.P., Mahanty, A., Ganguly, S., Sankar, T.V., Chakraborty, K., Anandan,R., Paul, B.N., Sarma, D., Mathew, S., Asha, K.K., Behera, B.K., Afftabuddin, M., Debnath, D., Vijaygopal, P., Sridhar, N., Akhtar, M.S., Sahi, N., Mitra, T., Banerjee, S., Paria, P., Das, D., Das, P., Vijayan, K.K., Lamanan, P.T., and Sharma, A.P. (2014). Amino Acid composition of 27 Food fishes and their importance in Clinical Nutrition. Journal of Amino acid, 1: 1-7. Doi.org/10.1155/2014/269797

Nargis, A. (2006). Seasonal variation in the chemical composition of body flesh of Koi fish, Anabas testudineus (Bloch), (Anabantidae: Perciformis). Bangladesh Journal of Scientific and Industrial Research, 41: 219-226

Pal, M. and Ghosh, M. (2013). Assay of Biochemical Compositions of two Indian freshwater Eel with special emphasis on accumulation of toxic heavy metals. Journal of Aquatic Food Production and Technology, 22: 27-35

Paul, B.N., Bhowmick, S., Chanda, S., Sridhar, N., and Giri, S.S. (2019). Nutrient Profile of Some Freshwater Fish Species. Pp 12. In Proc. Golden Jubilee International Conference on "Trends in Zoology". 03-04 Jan., 2019. The University of Burdwan, Burdwan, India

Paul, B.N., Bhowmick, S., Chanda, S., Sridhar, N., and Giri, S.S. (2018). Nutritional Values of Minor carps. SAARC Journal of Agriculture, 16(1): 215-231.

DOI: http://dx.doi.org/10.3329/sja.vl6i1.37436.

Paul, B.N., Chanda, S., Bhowmick, S., Sridhar, N., Saha, G.S., and Giri, S.S. (2017). Nutrient Profile of Indian Climbing Perch, Anabas testudineus. SAARC Journal of Agriculture, 15(1): 99-109. doi: http://dx.doi.org/10.3329/sja.vl5il.33156.

Paul, B.N., Chanda, S., Sridhar, N., Saha, G.S., and Giri, S.S. (2016). Fatty acid, Amino acid and Vitamin composition of Indian Catfish, Magur (Clarias batrachus) and Singhi (Heteropneustes fossilis).SAARC Journal of Agriculture, 14(2): 189199.Doi./org/10.3329/sja.v14i2.31258 
Paul, B.N., Chanda, S., Sridhar, N., Saha, G.S., and Giri, S.S. (2016a). Proximate, mineral and vitamin contents of Indian Major Carp. Indian Journal of Animal Nutrition, 33(1): 102-107. doi: 10.5958/2231-6744.2016.00018.9

Paul, B.N., Chanda, S., Sridhar, N., Saha, G.S., and Giri, S.S. (2015). Proximate and mineral composition of Magur (Clarias batrachus) and Singhi (Heteropneustes fossilis). Indian Journal of Animal Nutrition, 32(4):453-456.doi: 10.5958/2231-6744.2015.00017.1

Paul, B.N., Chanda, S., Sridhar, N., Saha, G.S., and Giri, S.S. (2015a). Fatty acid profile of Indian Major Carp. Indian Journal of Animal Nutrition, 32(2): 221-226

Paul, B.N., Chanda, S., Das, S., Singh, P., Pandey, B.K., and Giri, S.S. (2014). Mineral Assay in Atomic Absorption Spectroscopy. Beats of Natural Science, 1(4): 1-17

Roos, N., Islam, M.M., and Thilsted, S.H. (2003). Small fish is an important dietary source of vitamin A and calcium in Bangladesh. Journal of Nutrition, 133: 4021S-4026S

Sanchez-Alonso, I., Jimenez-Escrig, A., Saura-Calixto, F., and Borderias, A.J. (2007). Effect of grape antioxidant dietary fibre on the prevention of lipid oxidation in minced fish: Evaluation by different methodologies. Food Chemistry, 101: 372-378

Sankar, T.V., Susheela, M., Anandan, R., Asha, K.K., and Mohanty, B.P. (2010). Nutrient Profiling of Fish. ICAR-Central Institute of Fisheries Kochi, India.

Sargent, J.R. (1997). Fish oils and human diet. British Journal of Nutrition, 78: Suppl.1,S5$\mathrm{S} 13$

Schreckenbach, K., Knosche, R., and Ebert, K. (2001). Nutrient and energy content of freshwater fishes. Journal of Applied Ichthyology, 17: 142-144

Sener, E., Yildiz, M., and Savas, E. (2005). Effects of dietary lipids on growth and fatty acid composition in Russian sturgeon (Acipenser gueldenstaedtii) juveniles. Turkish Journal of Veterinary and Animal Science, 29: 1101-1107

Snedecor, G.W., and Cochran, W.G. (1968). Statistical Methods. $6^{\text {th }}$ ed. Oxford and IBH Publishing Company, Calcutta, India

Swapna, H.C., Kumar, R.A., Bhaskar, N., and Sachindra, N.M. 2010. Lipid classes and fatty acid profile of selected Indian freshwater fishes. Journal of Food Science and Technology, 47(4):394-400

Venugopal, V., Chawla, S.P., and Nair, P.M. (1996). Spray dried protein powder from threadfin beam: preparation properties and comparison with FPC type-B. Journal of muscle foods, 7: 55-71

Vlieg, P., and Body, D.B. (1988). Lipid contents and fatty composition of some New Zealand freshwater finfish and marine finfish, shellfish and roes. New Zealand Journal of Marine and Freshwater Research, 22: 151-162

Wang, Y.J., Miller, L.A., Perren, M., and Addis, P.B. (1990). Omega-3 fatty acids in Lake Superior fish. Journal of Food Science, 55(1): 71-76

Wheeler, S., and Morrissey, M.T. (2003). Quantification and distribution of lipid, moisture and fatty acids of West Coast Albacore tuna (Thunnus alalunga). Journal of Aquatic Food Product Technology, 12: 3-16.

WHO. (2007). Protein and amino acid requirement inhuman Nutrition: Report of a joint WHO/FAO/UNO Expert consultation. WHO Technical report series World Health organisation, Geneva, Swizerland 